\title{
Different levels of the fermented yellow cornmeal in diets for jelawat, Leptobarbus hoevenii
}

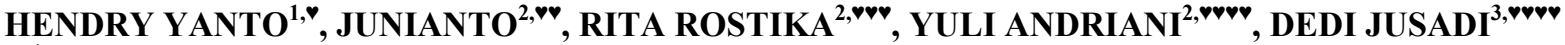 \\ ${ }^{1}$ Program in Aquaculture, Faculty of Fisheries and Marine Sciences, Universitas Muhammadiyah Pontianak. Jl. Jend. Ahmad Yani No. 111 \\ Pontianak 78124, West Kalimantan, Indonesia, " email: hendry fpikump@yahoo.co.id \\ ${ }^{2}$ Department of Fisheries, Faculty of Fisheries and Marine Sciences, Universitas Padjajaran. Jl. Bandung-Sumedang Km 21, Jatinangor, Sumedang \\ 45363, West Java, Indonesia. ${ }^{\text {}}$ email: anto lisc@yahoo.com, ${ }^{\text {}}{ }^{*}$ ritarostika unpad@yahoo.com, ${ }^{\text {}}{ }^{\vee}$ yuliyusep@yahoo.com \\ ${ }^{3}$ Department of Aquaculture, Faculty of Fisheries and Marine Sciences, Institut Pertanian Bogor. Jl. Lingkar Akademik, Kampus IPB Darmaga,

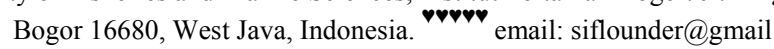

Manuscript received: 29 April 2017. Revision accepted: 20 November 2017.

\begin{abstract}
Yanto H, Junianto, Rostika R, Andriani Y, Jusadi D. 2017. Different levels of the fermented yellow cornmeal in diets for jelawat, Leptobarbus hoevenii. Nusantara Bioscience 9: 378-384. This research aimed to determine the optimum level of fermented yellow cornmeal in diets to improve the digestive enzyme activity, material digestibility coefficient, growth and feed efficiency for jelawat (Leptobarbus hoevenii Bleeker). The experimental treatments respectively used the fermented yellow cornmeal level of A1 $(10 \%)$, A2 (20\%), A3 (30\%), A4 (40\%), and two control groups of A5 (10\% of unfermented yellow corn meal) and A6 (commercial diet). The experimental diets with the same protein (isonitrogenous) and energy (isocaloric) were given to jelawat with an average size of $32.51 \pm 0.21 \mathrm{~g}$ per fish. The results showed that $\alpha$-amylase activity and carbohydrate digestibility value of the fermented yellow cornmeal increases along with the increasing feed levels. Protein and lipid of the body, retention of protein and lipid, daily growth rate and feeding efficiency were significantly different from each treatment $(\mathrm{P}<0.05)$. The fermented yellow cornmeal containing a level of $30 \%$ in the diet was the best for jelawat with an optimum level of $28.21-32.28 \%$ for the growth performance and feed efficiency of jelawat.
\end{abstract}

Keywords: Digestibility coefficient, enzyme activity, fermentation, Leptobarbus hoevenii, yellow cornmeal

\section{INTRODUCTION}

Jelawat (Leptobarbus hoevenii Bleeker) is one of freshwater fish types which has good cultivation development prospect. Southeast Asian people such as Indonesians, Malaysians, and Bruneians prefer jelawat very much that it brings it to have higher economic value, and in Indonesia, it is considered as one of exported commodities (Warta Pasarikan, 2010). The jelawat fingerlings have been mass produced by the artificial spawning technology to support its availability, particularly for fish growing cultivation. As omnivorous fish but tends to be herbivore, jelawat might consume various food which are relatively easy to find. The food habit brings the potential to utilize various feed made of plant materials efficiently.

Yellow corn is a local material utilized by fish as energy sources, and in the form of meal, it is commonly used in the formulation of fish diet and it still contains nutrients as energy sources. Economically, yellow corn meal is also easy to find in large quantities with relatively cheap price. Yellow cornmeal is expected to be utilized by jelawat as energy sources.

Fish are unable to utilize carbohydrates maximally. Fish ability to utilize carbohydrates are limited and various, for example, herbivorous fish groups are able to utilize carbohydrates of only $30-40 \%$ while omnivores are about $10-20 \%$ of their total diet formulation as their ability to produce amylase enzymes and insulin activities are low (Craig and Helfrich, 2009). Various efforts have been made for fish on the improvement of carbohydrate utilization efficiency and they are highly necessary.

Efforts to improve the carbohydrate utilization efficiency are by administering diet with optimum carbohydrate level. Excessive carbohydrates level in the diet may cause degeneration of liver cells, glycogen accumulation which stimulates lipid accumulation and liver disease on fish. It also decreases protein utilization efficiency and growth rate of sunshine bass, Marone chrysopsx and M. saxatilis (Hutchins et al. 1998), and those of European sea bass, Dicentrarchus labrax (Perez et al. 1997). In contrast, when carbohydrate level is low, it does not decrease the fish growth rate, but the diet price may become more expensive. The optimum level of carbohydrates should be maximally utilized as energy sources for fish.

Fermentation technology is another effort to improve the utilization of carbohydrates as energy sources in fish. Pawiroharsono (2007) suggested that fermentation is all kinds of metabolic processes assisted by enzymes generated from microorganisms to perform oxidation, reduction, hydrolysis, and other chemical reactions either in the anaerobic or aerobic condition which results in chemical changes of organic substrates. Fermentation aimed to simplify the complex compounds into the simple 
ones, to improve the diet digestibility and fish growth (Suprayudi et al. 2012 and Mulyasari et al. 2013). Fermentation may also improve the quality of diet materials better than before. Fermentation improved the content of protein (Cinma et al. 2014) and it also decreased the fiber, lipid, ash and phytic acid on fermentation material (Flores-Miranda et al. 2014). The fermented yellow cornmeal as feed material should be experimentally administered to jelawat. This research aimed to optimally determine the level of fermented yellow cornmeal in diet for the growth performance and feed efficiency of jelawat.

\section{MATERIALS AND METHODS}

This research was conducted at Center for Fish Hatchery of Pontianak from February to May 2016. This experiment used a completely randomized design with 6 treatments: fermented yellow corn meal of $10 \%$ (A1), $20 \%$ (A2), 30\% (A3), 40\% (A4), and two control groups, one with unfermented yellow corn flour of $10 \%$ (A5) while another with commercial diet of $10 \%$ (A6). Each treatment had 3 replications.

\section{Yellow cornmeal fermentation}

Yellow cornmeal was fermented with a fungus of Saccharomyces cerevisiae as suggested by Suprayudi et al. (2012). Yellow corn was smoothly mashed, added by water as much as $60 \% \mathrm{~kg}^{-1}$ material, and then steamed for 30 minutes for sterilization. Once yellow cornmeal was cold, it was then added with instant $S$. cerevisiae inoculums of $0.9 \% \mathrm{~kg}^{-1}$ material. Next, the yellow cornmeal mixture and inoculums were evenly stirred, and then put into a plastic container covered with newspaper sheets, and incubated for 24 hours at a room temperature. After that, the fermented yellow cornmeal was dried in an oven at a temperature of $60{ }^{\circ} \mathrm{C}$ for $15-16$ hours, and ready to use as the ingredient in diets for jelawat.

\section{The experimental fish and diets}

The experimental fish was jelawat with an average weight of $32.35 \pm 0.19 \mathrm{~g}$ obtained from the Fish Hatchery Center of Anjongan, West Kalimantan, Indonesia. The experimental diets were designed by containing the same protein (isonitrogenous) of $30 \%$ and energy (isocaloric) of $2,700 \mathrm{kcal} \mathrm{kg}^{-1}$. The feeding trial formulation was shown in Table 1, while the analytical results of feed proximate and starch were shown in Table 2.

Table 1. Formulation of the experimental diets for jelawat according to the treatments $(\%)^{1)}$

\begin{tabular}{llllll}
\hline \multirow{2}{*}{ Ingredients } & \multicolumn{5}{c}{ Experimental diets (\%) } \\
\cline { 2 - 6 } & $\mathbf{A 1}$ & $\mathbf{A 2}$ & $\mathbf{A 3}$ & $\mathbf{A 4}$ & $\mathbf{A 5}$ \\
\hline Fish meal & 30.00 & 30.00 & 30.00 & 30.00 & 30.00 \\
Soybean meals & 8.85 & 8.70 & 8.50 & 8.35 & 10.35 \\
Squid meal & 5.00 & 5.00 & 5.00 & 5.00 & 5.00 \\
Fermented yellow cornmeal & 10.00 & 20.00 & 30.00 & 40.00 & 0.00 \\
Unfermented yellow cornmeal & 0.00 & 0.00 & 0.00 & 0.00 & 10.00 \\
Pollard & 32.00 & 22.00 & 12.00 & 2.00 & 32.00 \\
Tapioca flour & 5.00 & 5.00 & 5.00 & 5.00 & 5.00 \\
Fish oil & 2.00 & 2.00 & 2.00 & 2.00 & 2.00 \\
Corn meal & 1.50 & 1.50 & 1.50 & 1.50 & 1.50 \\
Palm oil & 1.35 & 1.00 & 0.80 & 0.50 & 0.30 \\
Vitamin mix & 1.00 & 1.00 & 1.00 & 1.00 & 1.00 \\
Mineral mixt & 1.00 & 1.00 & 1.00 & 1.00 & 1.00 \\
Cellulose & 2.30 & 2.80 & 3.20 & 3.65 & 1.85 \\
\hline Note: 1 Fors & Fon &
\end{tabular}

Note: 1) Formulation of diet did not include commercial diet; 2) every kg of vitamin mixture contained: vit. A 3,000,000 IU; vit. D3 1,000,000 IU; vit. K3 1,200 mg; vit. E 7,500 mg; vit. B1 3,000 mg; vit. B2 4,500 mg; vit B6 3,000 mg; vit. B12 3,000 mg; vit. C 8,000 mg; Ca panthotenate 4,500 mg; Folic acid 1,500 mg; Biotin 1,000 mg; Inositol 12,500 mg; Nicotinamide 20,000 mg; Choline chloride 15,000 mg; L-Lysine 20,000 mg; DL-Methionine 5,000 mg and 3) every $100 \mathrm{~g}$ of mineral containing: $\mathrm{NaCl} 1.00 \mathrm{~g}$ macro minerals; $\mathrm{MgSO}_{4} 7 \mathrm{H}_{2} \mathrm{O} 15.00 \mathrm{~g} ; \mathrm{NaH}_{2} \mathrm{PO}_{4} \mathrm{H}_{2} \mathrm{O} 25.00 \mathrm{~g} ; \mathrm{KH}_{2} \mathrm{PO}_{4} 32.00 \mathrm{~g}$; Ca $\left(\mathrm{H}_{2} \mathrm{PO}_{4}\right) 2 \mathrm{H}_{2} \mathrm{O} 20.00 \mathrm{~g}$; Fe-citrate 2.50 g; Trace element mix 1.00 g; Ca-lactate 3.50 g; micro minerals $\mathrm{ZnSO}_{4} 7 \mathrm{H}_{2} \mathrm{O} 35.30 \mathrm{~g} ; \mathrm{MnSO}_{4} \mathrm{H}_{2} \mathrm{O} 16.20 \mathrm{~g} ; \mathrm{CuSO}_{4} 5 \mathrm{H}_{2} \mathrm{O} 3.10$ g; $\mathrm{CoCl}_{2} 6 \mathrm{H}_{2} \mathrm{O} 0.10$ g KIO 30.30 g and $45.00 \mathrm{~g}$ cellulose

Table 2. Proximate and starch analysis results of the experimental diets according to the treatments (in dry weight) ${ }^{1)}$.

\begin{tabular}{|c|c|c|c|c|c|c|}
\hline \multirow{2}{*}{ Nutrients } & \multicolumn{6}{|c|}{ Experimental diets } \\
\hline & $\mathbf{A 1}$ & $\mathbf{A 2}$ & $\mathbf{A 3}$ & A4 & A5 & A6 \\
\hline Protein $(\%)$ & 30.07 & 30.05 & 30.07 & 30.03 & 30.25 & 30.96 \\
\hline Lipid (\%) & 10.57 & 10.68 & 10.48 & 10.31 & 10.95 & 8.05 \\
\hline $\operatorname{Ash}(\%)$ & 12.29 & 11.56 & 11.10 & 11.05 & 12.10 & 16.24 \\
\hline Crude fiber $(\%)$ & 6.78 & 6.35 & 6.39 & 6.48 & 6.45 & 5.11 \\
\hline Nitrogen-free extract $(\%)^{2)}$ & 40.29 & 41.36 & 41.96 & 42.13 & 40.25 & 39.64 \\
\hline Digestibility energy (kcal) ${ }^{3)}$ & $2,693.04$ & $2,718.6$ & $2,712.6$ & $2,700.8$ & $2,730.0$ & $2,436.4$ \\
\hline Ratio Energy/Protein & 8.96 & 9.05 & 9.02 & 8.99 & 9.02 & 7.87 \\
\hline Starch $(\%)$ & 29.36 & 30.41 & 32.76 & 33.47 & 28.25 & 29.19 \\
\hline
\end{tabular}

Note: 1) The water content of A1 $=4.52 \%$; A2 $=4.64 \%$; A3 $=4.74 \%$; A4 = 4.51 \%; A5 = 4.40 \%; A6 = 5.28 \%; 2) Nitrogen free extract (carbohydrate), and 3) Calculated according to an energy value of protein $4 \mathrm{kcal} \mathrm{g}^{-1}$, lipid $8 \mathrm{kcal} \mathrm{g}^{-1}$ and carbohydrate $1.6 \mathrm{kcal}^{-1}$ 


\section{Fish husbandry}

Jelawat with an average weight of $32.54 \pm 0.21 \mathrm{~g}$ was cultivated in an aquarium with a size of $60 \times 40 \times 40 \mathrm{~cm}$ and a total of 18 units. Aquarium was equipped with aeration system as the oxygen supply, while the top was covered with black wiring to prevent fish jumping out. Each aquarium was filled with water for up to $30 \mathrm{~cm}$ high that the volume reaches $72 \mathrm{~L}$. Fish density was only 10 per unit. Within 60 days of treatment, jelawat fish were fed until satisfied (at satiation) with the experimental diets based on each treatment with administration frequency of three times respectively at 8 a.m., 12 p.m., and 4 p.m. every day. Each aquarium was then cleaned every morning before feeding, and water replacement was made with $70 \%$ of the total water volume. Water quality might support jelawat to live and grow normally with the following criteria: dissolved oxygen of 5.75 to $6.50 \mathrm{ppm}$ of, the temperature of $28-31{ }^{\circ} \mathrm{C}$, acidity degree $(\mathrm{pH})$ of $6.30-6.50$, and ammonia total amount of 0.2-0.4 ppm. The water quality was sufficient to support the life and growth of jelawat. This resulted in $100 \%$ survival rate of jelawat in all experimental units.

\section{Digestibility coefficient test of the fermented and nonfermented yellow cornmeal}

The digestibility coefficient test of the fermented and unfermented yellow corn meal by collecting fish feces was conducted for three weeks. The whole fish of each even treatment replication were combined into one and then cultivated at the density of 10 fish for each experimental unit. Those fish were fed with the reference diet mixed with the fermented and unfermented yellow cornmeal according to the treatments. The reference diet was commercial pellet which was smoothly mashed as conducted by Suprayudi et al. (2012) and Mulyasari et al. (2013). The mixture comparisons between reference diet and tested fermented yellow cornmeal based on treatments were respectively $90 \%$ and $10 \% ; 80 \%$ and $20 \% ; 70 \%$ and $30 \% ; 60 \%$ and $40 \%$. Besides of those, the mixture comparison between $90 \%$ of the commercial diet and $10 \%$ of unfermented yellow corn meal was a control diet. Those diets were added with chromium oxide $\left(\mathrm{Cr}_{2} \mathrm{O}_{3}\right)$ of $0.5 \%$ might be used as a marker to distinguish between the remaining feed and feces (Takeuchi, 1988). The diets were remade into pellets once again with the addition of carboxymethyl cellulose (CMC) $1 \%$, and then dried (Mulyasari et al. 2013). The diet was then given to fish until satisfied with a frequency of 3 times, at 8 a.m., 12 p.m., and 4 p.m. every day. Fish feces was immediately taken and adequately collected for proximate and chromium feces analytical purposes.

\section{Chemical analysis}

Proximate analysis was conducted on materials used to make diets, experimental diets, jelawat body, and fish feces. Proximate analysis of jelawat body was conducted by taking three fish samples of each experimental unit. The water content was measured by heating the sample material for 24 hours in an oven at a temperature of $65^{\circ} \mathrm{C}$; crude protein level was measured using the Kjeldahl method, while the fat content was measured using Folch method (Takeuchi, 1988).

The starch analysis contained within experimental feed was conducted by an acid hydrolysis method (Sudarmadji et al. 1993). The determination of glucose obtained from starch was similar with that of glucose reducing agent using a spectrophotometer at a wavelength of $540 \mathrm{~nm}$. Glucose weight was multiplied by 0.9 to calculate the starch. Starch content was calculated with the following formula: starch $\%=$ (concentration $\mathrm{x}$ dilution) $/$ sample weight (g) x $100 \%$ x 0.9 .

Fish intestines taken from the three fish of each experimental unit were combined with distilled water up to ten times of the sample weight and then homogenized that resulted in crude enzyme extract. Next, the enzyme extract was stored in a refrigerator (with a temperature of $-20{ }^{\circ} \mathrm{C}$ ) until enzyme activity test was conducted. Protease activity was conducted with Hans-Helmar Walter method, lipase activity with Borlongan method, and $\alpha$-amylase activity with Bernfeld method (Handayani 2006).

The determination of diet and feces chromium $\left(\mathrm{Cr}_{2} \mathrm{O}_{3}\right)$ content was conducted based on Takeuchi method (1988). Samples were destructed with $5 \mathrm{~mL}$ of concentrated nitric acid for 30 minutes until the volume was only about $1 \mathrm{~mL}$, and subsequently cooled and added with $3 \mathrm{~mL}$ of concentrated perchloric acid $\left(\mathrm{HClO}_{4}\right)$. The mixture was heated that the solution turns into orange, cooled, diluted to $100 \mathrm{~mL}$, and the absorption value was read with a spectrophotometer at a wavelength of $350 \mathrm{~nm}$.

\section{Data analysis}

The digestibility coefficient of fermented and unfermented yellow cornmeal was calculated with the formula proposed by Law (1984) as well as Anderson and De Silva (2006) as follows: $I=100 / a-(t-b / 100 r)$. Where: $I=$ digestibility coefficient of the test ingredient $(\%), a=$ percentage of test ingredient, $b=$ percentage of the referential diet, $t=$ nutrient digestibility coefficient of the tested diet, and $r=$ nutrient digestibility coefficient of the referential diet.

The HSI value calculated with a formula used by Higgs et al. (2009) was as follows: $H S I=((W H) /(W B)) \times 100 \%$. Where $H S I=$ hepatosomatic index $(\%), W H=$ liver weight (g) and $W B=$ body weight (g).

Protein retention and lipid were calculated using the formula proposed by Takeuchi (1988) as follows: $R N=(N t$ - No) / $N p$ x $100 \%$. Where $R N=$ nutrient retention, such as protein or lipid $(\%), N t=$ fish body protein or fat content at the end of experiment $(\%), N o=$ fish body protein or lipid content at the beginning of experiment $(\%)$, and $N p=$ feed protein or lipid content (\%).

The daily growth rate was calculated using a formula proposed by Huisman (1976): $W t=W_{O}(1+0.01 \alpha) \mathrm{t}$. Where $W t=$ fish biomass end-weight average $(\mathrm{g}), W_{o}=$ fish biomass initial weight average $(\mathrm{g}), t=$ research period of time (day) and $\alpha=$ daily growth rate (\%).

Feeding efficiency was calculated with a formula proposed by Higgs et al. (2009) as follows: $e=F /$ (Wt$W o) \times 100 \%$. Where, $e=$ feeding efficiency $(\%), F=$ feed total amount given during experiment $(\mathrm{g}), W t=$ final fish 
biomass weight (g), and $W o=$ initial fish biomass weight (g).

Variables consisting of digestive enzyme activity, HSI, fish body protein and lipid content, protein and lipid retention, daily growth rate, and feed efficiency were statistically analyzed with one-way analysis of variance (ANOVA), and Duncan's multiple range test to determine the best treatment. Differences were considered significant at $\mathrm{P}<0.05$. Meanwhile, the material digestibility value was descriptively analyzed. Regression analysis was conducted to determine the optimum level of fermented yellow cornmeal. In addition, statistical analysis was then conducted using PASW Statistics software version 18.

\section{RESULTS AND DISCUSSIONS}

\section{Enzyme activity}

The activities of protease and lipase were not significant $\quad(\mathrm{P}>0.05)$, but $\alpha$-amylase activity was significantly different among the treatments $(\mathrm{P}<0.05)$. There was an increasing tendency of $\alpha$-amylase activity along with the increasing proportion of fermented corn contained in the diets. The activity of $\alpha$-amylase in treatment A5 was the lowest one, while the highest was in treatment A4 (Table 3).

\section{Fermented and unfermented yellow corn meal digestibility coefficients}

Digestibility coefficients of protein, lipid, and ash decreased, while those of carbohydrate (nitrogenfree extract, NFE) and total energy increased along with the increasing levels of the fermented yellow corn meal contained in diets. Digestibility coefficients of protein, lipid, ash, carbohydrate and total energy of fermented yellow corn meal were higher than unfermented one in the equal proportion (Table 4).

\section{Body compositions}

Body protein and lipid after treatment increased when compared to those before treatment. The highest body protein and lipid, as well as protein and lipid retentions, were resulted by the diet containing $30 \%$ fermented yellow cornmeal (A3) while the lowest ones were in the diet containing unfermented yellow corn meal of $10 \%$ (A5). The levels of protein and lipid body, protein and lipid retention of jelawat were significantly different among the treatments $(\mathrm{P}>0.05)$ (Table 5).

Table 3. Protease, lipase and $\alpha$-amylase activities (u mg ${ }^{-1}$ protein) of jelawat at the end of experiment

\begin{tabular}{llll}
\hline \multirow{2}{*}{ Treatments } & \multicolumn{3}{c}{ Enzyme Activities (u mg $\mathbf{~ p r o t e i n})^{-1}$ } \\
\cline { 2 - 4 } & Protease & Lipase & $\boldsymbol{\alpha}$ Amylase \\
\hline A1 & $5,24 \pm 0,03^{\text {a }}$ & $0,15 \pm 0,02^{\text {a }}$ & $21,14 \pm 0,04^{\text {a }}$ \\
A2 & $5,23 \pm 0,02^{\text {a }}$ & $0,15 \pm 0,03^{\text {a }}$ & $22,96 \pm 0,50^{\text {b }}$ \\
A3 & $5,22 \pm 0,01^{\text {a }}$ & $0,14 \pm 0,01^{\text {a }}$ & $23,86 \pm 0,55^{\text {c }}$ \\
A4 & $5,19 \pm 0,03^{\text {a }}$ & $0,15 \pm 0,02^{\text {a }}$ & $25,89 \pm 0,28^{\text {d }}$ \\
A5 & $5,22 \pm 0,03^{\text {a }}$ & $0,15 \pm 0,01^{\text {a }}$ & $20,65 \pm 0,03^{\text {a }}$ \\
A6 & $5,23 \pm 0,03^{\text {a }}$ & $0,13 \pm 0,01^{\text {a }}$ & $21,14 \pm 0,57^{\text {a }}$ \\
\hline
\end{tabular}

Note: Means with a common superscript letter in the same column were not significantly different $(\mathrm{P}>0.05)$ by Duncan's test

Table 4. Digestibility coefficient of protein, lipid, ash, carbohydrate (NFE), and total energy (\%) of the fermented and unfermented yellow corn meal based on treatments given to jelawat

\begin{tabular}{|c|c|c|c|c|c|}
\hline Treatments & Protein & Lipid & Ash & NFE $^{1)}$ & Total energy \\
\hline $\begin{array}{l}\text { A1 }(90 \% \text { reference diet }+10 \% \\
\text { fermented yellow cornmeal })\end{array}$ & $78.65 \pm 0.01$ & $84.17 \pm 0.01$ & $75.95 \pm 0.04$ & $79.99 \pm 0.01$ & $73.65 \pm 0.01$ \\
\hline $\begin{array}{l}\text { A2 }(80 \% \text { reference diet }+20 \% \\
\text { fermented yellow cornmeal })\end{array}$ & $75.54 \pm 0.01$ & $74.27 \pm 0.03$ & $49.40 \pm 0.03$ & $88.68 \pm 0.02$ & $79.61 \pm 0.01$ \\
\hline $\begin{array}{l}\text { A3 }(70 \% \text { reference diet }+30 \% \\
\text { fermented yellow cornmeal) }\end{array}$ & $73.28 \pm 0.01$ & $69.46 \pm 0.01$ & $40.20 \pm 0.01$ & $92.06 \pm 0.02$ & $81.67 \pm 0.01$ \\
\hline $\begin{array}{l}\text { A4 }(60 \% \text { reference diet }+40 \% \\
\text { fermented yellow cornmeal })\end{array}$ & $70.74 \pm 0.01$ & $64.84 \pm 0.01$ & $35.86 \pm 0.02$ & $97.33 \pm 0.01$ & $84.77 \pm 0.01$ \\
\hline $\begin{array}{l}\text { A5 }(90 \% \text { reference diet }+10 \% \\
\text { unfermented yellow cornmeal) }\end{array}$ & $51.17 \pm 0.00$ & $52.78 \pm 0.01$ & $51.01 \pm 0.06$ & $57.64 \pm 0.02$ & $44.53 \pm 0.01$ \\
\hline
\end{tabular}

Note: 1) Nitrogenfree extract (carbohydrate)

Table 5. Protein and lipid body, protein, and lipid retention of jelawat before and after treatments (in dry weight) as well as Hepatosomatic Index (HSI) (in wet weight) (\%)

\begin{tabular}{lccccc}
\hline \multirow{2}{*}{ Treatments } & \multicolumn{5}{c}{ Body compositions } \\
\cline { 2 - 6 } & Protein & Lipid & Protein retention & Lipid retention & Hepatosomatic index \\
\hline Initial & 48.71 & 20.46 & - & - & \\
A1 & $49.09 \pm 0.66^{\mathrm{a}}$ & $22.06 \pm 0.39^{\mathrm{a}}$ & $27.21 \pm 1.49^{\mathrm{b}}$ & $35.57 \pm 0.73^{\mathrm{b}}$ & $1.18 \pm 0.01^{\mathrm{b}}$ \\
A2 & $52.08 \pm 0.13^{\mathrm{b}}$ & $23.27 \pm 0.70^{\mathrm{ab}}$ & $34.05 \pm 1.56^{\mathrm{c}}$ & $43.34 \pm 0.51^{\mathrm{c}}$ & $1.26 \pm 0.01^{\mathrm{c}}$ \\
A3 & $54.72 \pm 0.65^{\mathrm{c}}$ & $24.68 \pm 0.13^{\mathrm{c}}$ & $37.27 \pm 1.52^{\mathrm{d}}$ & $51.35 \pm 0.39^{\mathrm{e}}$ & $1.36 \pm 0.01^{\mathrm{d}}$ \\
A4 & $52.70 \pm 0.23^{\mathrm{b}}$ & $23.85 \pm 0.74^{\mathrm{bc}}$ & $34.07 \pm 1.31^{\mathrm{c}}$ & $45.65 \pm 0.27^{\mathrm{d}}$ & $1.44 \pm 0.01^{\mathrm{e}}$ \\
A5 & $48.77 \pm 0.34^{\mathrm{a}}$ & $22.54 \pm 0.57^{\mathrm{a}}$ & $21.68 \pm 1.42^{\mathrm{a}}$ & $28.54 \pm 0.73^{\mathrm{a}}$ & $1.11 \pm 0.02^{\mathrm{a}}$ \\
A6 & $51.62 \pm 0.61^{\mathrm{b}}$ & $22.58 \pm 0.08^{\mathrm{a}}$ & $27.64 \pm 1.14^{\mathrm{b}}$ & $46.99 \pm 0.67^{\mathrm{d}}$ & $1.18 \pm 0.01^{\mathrm{b}}$ \\
\hline
\end{tabular}

Note: means with a common superscript letter in the same column were not significantly different (P>0.05) by Duncan's test. 
Table 6. The initial and final weight, daily growth rate, total feed consumption and feeding efficiency of jelawat cultivated for 60 days

\begin{tabular}{|c|c|c|c|c|c|}
\hline \multirow{2}{*}{ Treatments } & \multicolumn{5}{|c|}{ Utilization parameters of diet } \\
\hline & $W_{0}(g)^{1)}$ & $W_{t}(g)^{2)}$ & DGR $(\%)^{3)}$ & FC $(g)^{4)}$ & FE $(\%)^{5)}$ \\
\hline A1 & $326.33 \pm 1.53$ & $1,279.00 \pm 7.94$ & $2.30 \pm 0.02^{b}$ & $1,522.33 \pm 2.52^{\mathrm{a}}$ & $65.58 \pm 0.62^{\mathrm{b}}$ \\
\hline $\mathrm{A} 2$ & $322.67 \pm 1.55$ & $1,372.33 \pm 20.03$ & $2.44 \pm 0.02^{\mathrm{c}}$ & $1,510.00 \pm 15.00^{\mathrm{a}}$ & $69.52 \pm 1.83^{\mathrm{c}}$ \\
\hline A3 & $324.67 \pm 2.08$ & $1,515.67 \pm 12.90$ & $2.60 \pm 0.01^{\mathrm{e}}$ & $1,515.00 \pm 5.00^{\mathrm{a}}$ & $78.18 \pm 0.62^{\mathrm{e}}$ \\
\hline A4 & $327.33 \pm 2.08$ & $1,424.00 \pm 7.94$ & $2.48 \pm 0.02^{\mathrm{d}}$ & $1,518.00 \pm 3.61^{\mathrm{a}}$ & $72.25 \pm 0.40^{\mathrm{d}}$ \\
\hline A5 & $326.33 \pm 2.08$ & $1,165.00 \pm 16.09$ & $2.14 \pm 0.02^{\mathrm{a}}$ & $1,509.67 \pm 10.22^{\mathrm{a}}$ & $55.55 \pm 1.11^{\mathrm{a}}$ \\
\hline A6 & $325.33 \pm 1.53$ & $1,287.33 \pm 7.77$ & $2.32 \pm 0.02^{\mathrm{b}}$ & $1,516.67 \pm 7.64^{\mathrm{a}}$ & $63.43 \pm 0.87^{b}$ \\
\hline
\end{tabular}

Note: 1) initial weight, 2) final weight, 3) daily growth rate, 4) feed consumption, and 5) feed efficiency. Means with a common superscript letter in the same column were not significantly different $(\mathrm{P}>0.05)$ by Duncan's test.

According to the regression analysis, correlation of between the fermented yellow cornmeal and body protein formed the quadratic equation $y=-0.0125 \mathrm{x}^{2}+0.7609 \mathrm{x}+$ 42.518 with $\mathrm{R}^{2}=0.9429$. It meant that the optimum level of yellow cornmeal was $30.44 \%$ to produce the maximal body protein. While the correlation of between the fermented yellow cornmeal and body lipid formed quadratic equation, and it was $\mathrm{y}=-0.0051 \mathrm{x}^{2}+0.3228 \mathrm{x}+$ 19.22 with $\mathrm{R}^{2}=0.9181$. The optimum level of yellow cornmeal in the diet to produce the maximal body lipid was $32.28 \%$. The optimum level of fermented yellow cornmeal in the diet to result the maximum protein retention amounted to $29.78 \%$ by quadratic equation $y=-0.025 \mathrm{x}^{2}+$ $1.489 \mathrm{x}+14.688$ and $\mathrm{R}^{2}=0.9932$ Based on regression analysis, it was formulated to $\mathrm{y}=-0.0387 \mathrm{x}^{2}+2.2974 \mathrm{x}+$ 16.07 with $\mathrm{R}^{2}=0.9756$. The optimum fermented yellow cornmeal proportion in the diet to produce maximum lipid retention was $29.84 \%$ for jelawat.

Hepatosomatic index (HSI) tended to increase with an increase in the proportion of fermented yellow cornmeal in the diet. HSI on the diets containing fermented yellow cornmeal was higher than unfermented one. The highest HSI was the diet containing the fermented yellow cornmeal $40 \%$ (A4), and the lowest one was the diet containing $10 \%$ of unfermented yellow cornmeal (A5). HSI was significantly different among the treatments $(\mathrm{P}<0,05)$.

\section{Utilization of diet}

The lowest daily growth rate was in treatment A5 (unfermented yellow cornmeal 10\%) while the highest was in treatment A3 (fermented yellow cornmeal 30\%). The daily growth rate of jelawat was significantly different in each treatment (Table 6). According to the regression analysis, the optimal level of fermented rice bran in the diet was $28.21 \%$ of the total diet formulation for jelawat. It was based on quadratic equation $\mathrm{y}=-0,0007 \mathrm{x}^{2}+0,0395 \mathrm{x}+$ 1.955 and $\mathrm{R}^{2}=0.902$.

The feed efficiency was significantly different among the treatments $(\mathrm{P}<0.05)$. The lowest feed efficiency was in the diet containing $10 \%$ of unfermented yellow corn meal and the highest one was in the diet containing $30 \%$ of fermented yellow cornmeal. All fermented yellow cornmeal in the diets producing the feed efficiencies were higher than the diet containing the unfermented yellow cornmeal. Then the maximum feed efficiency produced by optimum fermentation levels of rice bran in the diet was
$30.18 \%$ with the equation $\mathrm{y}=-0,0358 \mathrm{x}^{2}+2,1006 \mathrm{x}+$ 43.825 and $\mathrm{R}^{2}=0.9186$.

\section{Discussion}

Protease and lipase enzyme activities were not significantly different because the protein and lipid content of diets as enzyme substrate were relatively the same. Fish enzyme activity was positively correlated with substrate level contained within diets (Krogdhal et al. 2005). For example, gouramy (Osphronemus goramy) fed with different carbohydrate levels but with the same protein content generated the same protease activity after cultivated for 60 days (Handayani, 2006). In addition, sea bass fish larva (Dicentrarchus labrax) had lipase enzyme and phospholipase A2 (PL A2) activities which were not different because the diet was given with a relative same lipid content with triglycerides and phospholipids as lipase substrates (Zambonino and Cahu, 1999). Protease and lipase activities were along with protein and lipid content as the substrates in the diets.

The difference of $\alpha$-amylase activity was in correlation with the increasing starch content along with the increasing carbohydrate proportion and fermented yellow cornmeal in the diets (Tabel 2). Starch was substrate hydrolyzed by $\alpha$ amylase (Krogdahl et al. 2005). For example, the larva of sea bass (Dicentrarchus labrax) had higher $\alpha$-amylase activity when its diet was with than without starch (Cahu et al. 2004). Thus, starch content and proportion of the fermented yellow cornmeal in the diets influenced the $\alpha$ amylase activity of jelawat.

Some studies showed that the increase of carbohydrate in the diet influenced starch content in the diet and $\alpha$ amylase activity of fish. For example, the increasing of carbohydrate in diet had also increased $\alpha$-amylase activity of common carp, Cyprinus carpio (Kesavanath et al. 2002), Labeo rohita (Mohapatra et al. 2003), gouramy, O. goramy (Handayani, 2006), spiny lobster, Jasus edwarsii (Simons et al. 2011), grass carp, Ctenopharyngodon idella (Shan et al. 2013). The increasing $\alpha$-amylase activity was resulted in starch modulation of carbohydrate in the diet as an enzyme substrate.

The decreasing digestibility coefficients of protein, lipid, and ash, as well as the increasing carbohydrate digestibility coefficients of the fermented yellow corn meal, were related to the increase of their level in the diets. Similarly, Handadjani and Widodo (2010) stated that the increasing carbohydrate in the diets potentially decreased 
the digestibility coefficients of protein, lipid, and other nutrients. For example, the increasing levels of dextrin and glucose as carbohydrate sources in diet of rainbow trout (Oncorhynchus mykiss) decreased the digestibility coefficient of both protein and lipid materials, but increased the carbohydrate digestibility coefficient (Storebakken et al. 1998), as well as those in gouramy, $O$. goramy (Handayani, 2006).

Digestibility coefficients of protein, lipid, ash, carbohydrates and gross energy of the fermented yellow corn meal were higher than the unfermented one as the fermented yellow corn meal undergoing processes, such as steam. The steaming of feed material, such as corn, might increase the starch digestibility value of $50 \%$ (Handadjani and Widodo, 2010). Furthermore, fungus addition of $S$. cerevisiae might also increase the value of digestibility and nutrient content materials since fungus produces enzymes, such as carbohydrase, protease, lipase, mannanase and ligninase that fermented materials were much better than the unfermented ones (Suprayudi et al. 2012). Thus, the fermented yellow cornmeal had nutrient digestibility coefficient better than the unfermented one.

Jelawat consumed the diet with the proportion of fermented yellow corn meal by $30 \%$ produced the highest body protein and lipid in jelawat. That diet had the balance of carbohydrate and protein. Thus, carbohydrate energy generated from the fermented yellow cornmeal in the diet might be maximally utilized by jelawat as metabolic energy sources, so that protein and lipid might be efficiently utilized to support growth. Furthermore, carbohydrate energy generated from the fermented yellow cornmeal might also be used for synthesizing non-essential amino acids and lipids in the body to support growth (Bedner and Mayes, 2006). Therefore, the content of fermented yellow cornmeal as much as $30 \%$ in the diet was the best one to produce the highest protein and lipid of the body in jelawat. However, according to the regression analysis, the optimum fermented yellow cornmeal in the diet to produce maximum body protein was $30.44 \%$ and the maximum body lipid produced by optimum fermented yellow cornmeal was $32.28 \%$ in the diet.

Along with high body protein and lipid in jelawat which consumed the diet containing $30 \%$ of fermented yellow cornmeal, it was the best one to produce the protein and lipid retentions in jelawat. However, according to the regression analysis, the optimum fermented yellow corn meal level in the diet was $29.78 \%$ to result in the maximum protein retention. Then the maximum lipid retention was produced by the diet containing optimum fermented yellow cornmeal amounted to $29.84 \%$.

Hepatosomatic index (HSI) tended to increase due to the increasing levels of the fermented yellow cornmeal as carbohydrate energy increased in the diets, and also subsequently increased glycogen and lipid content in the liver. In addition, the increase of glycogen and lipid in the liver also increased HSI of jelawat.

HSI generated from treatments with carbohydratesource of the fermented yellow cornmeal (A1-A4) in the diets were higher than the unfermented one (treatment A5) due to the high $\alpha$-amylase activity and carbohydrate digestibility coefficients of jelawat. The condition resulted in higher blood glucose of jelawat consuming the fermented yellow cornmeals than the unfermented one. Furthermore, the glucose was utilized as metabolic energy sources while the remaining one was stored as glycogen and lipid by jelawat. Fish ability to utilize carbohydrates depended on its ability to oxidize glucose from digested carbohydrates, and stored as glycogen and lipid (Zhang et al. 2009). The more the glycogen and lipid were stored in the liver, the higher the HSI increased, along with the increasing carbohydrate energy in the diet. Similarly, the higher the HSI the higher the glycogen increased in the fish liver, such as experienced by the European seabass, Dientrarchus labrax (Perez et al. 1997); Asian seabass, Lates calcarifer (Catacutan and Coloso, 1997); sunshine bass fingerling, female Marone chrysops $x$ male $M$. saxalitis (Hutchin et al. 1998); halibut Atlantic fish, Hippoglossus hipoglossus (Hatlen et al. 2005); European sea bass fish, Dicentrarchus labrax (Moreira et al. 2008), transgenic coho salmon fish, Oncorhynchus kisutch Walbaum (Higgs et al. 2009) and seabass, Dicentrarchus labrax (Gatesoupe et al. 2014).

The accumulation of $\alpha$-amylase activity, coefficient of nutrient digestibilities (protein, lipid, carbohydrate, total energy), protein and lipid retentions occurred in jelawat consuming the diets with the fermented yellow cornmeal content and it produced higher daily growth rate and feed efficiency higher than diets with the unfermented yellow cornmeal. Feeding the diet containing the fermented carbohydrate sources produced the highest growth rate and feed efficiency in tawes, Puntius javonicus (Rostika, 2010), common carp, C. Carpio (Suhenda et al. 2010; Suprayudi et al. 2012), catfish hybrid, Heteroclarias spp. (Obe and Worula, 2014). Fermented yellow cornmeal produced the growth rate and feed efficiency better than the unfermented one for jelawat.

Zhang et al. (2009) explained that when carbohydrates were digested by fish, the ability to utilize carbohydrates as energy sources to support growth depended on the metabolic enzymes and assimilations. For instance, coho salmon (O. kisutch Walbaum) was able to increase the growth hormone activity, insulin growth hormone (IGF-1), and 3,5,3-triiodothyronine to support growth when the optimal carbohydrate contained in the diet was $168 \mathrm{~g} / \mathrm{kg}$ (Higgs et al. 2009). Conversely, when carbohydrate was too high in the diet of grass carp (Ctenopharyngodon Idella), it might result in the increasing pyruvate kinase enzyme activity and mRNA expression involved in liver glycolytic regulation that the growth, as well as feed intake and utilization, decreased (Yuan et al. 2013). Carbohydrates contained in diet had to be optimum and balance with the other nutrients such as protein and lipid in the diet.

The highest daily growth rate of jelawat consuming the diet containing $30 \%$ of yellow cornmeal was the accumulation of protein and lipid in the body as well as that of the highest protein and lipid retentions. Based on the regression analysis, the optimum of fermented yellow cornmeal contained in the diet of jelawat was $28.21 \%$ to result in maximum daily growth rate. On the other hand, 
jelawat which consumed $30 \%$ of fermented yellow cornmeal in the diet resulted in the highest feed efficiency related to high body protein and lipid, protein and lipid retention, as well as the daily growth rate. Thus the optimal level of fermented yellow cornmeal contained in the diet to generate maximum feeding efficiency of jelawat was 30.18 $\%$.

To conclude, the levels of fermented yellow cornmeal in the diets resulted in the body protein and lipid, protein and lipid retention, daily growth rate, and feeding efficiency which was significantly different $(\mathrm{P}<0.05)$. The optimum level of fermented yellow cornmeal to support the growth performance and feed efficiency of jelawat ranged from 28.21 to $32.28 \%$ of the total diet formulation.

\section{REFERENCES}

Anderson T, De Silva S. 2006. Nutrition. In: Lucas SJ, Southgate CP. (eds.). Aquaculture, Farming Aquatic Animals, and Plants. Blackwell Publishing, New York.

Bedner AD, Mayes, AP. 2006. Physiologically important carbohydrates. In: Harper RK, Murray DA, Granner, Rodwell VW. (eds). Harper Biochemistry. EGC, Jakarta. [Indonesian]

Cahu C, Ronnested I, Grangier, Zambonino JL. 2004. Expression and activities of the pancreatic enzyme in developing sea bass larvae (Dicentrarchus labrax) in relation to intact and hydrolyzed dietary protein; involvement of cholecystokinin. Aquaculture 238: 295-308

Catacutan MR, Coloso MR. 1997. The growth of juvenile Asian seabass, Lates calcarifer, fed varying carbohydrate and lipid levels. Aquaculture 149: 137-144.

Chinma CF, Ilowefah M, Muhammad K. 2014. Optimation of rice bran fermentation condition enhanced by Baker's yeast for extraction of protein concentrate. Nigerian Food J 32 (1): 126-132.

Craig S, Helfrich AL. 2009. Understanding Fish Nutrition, Feeds, and Feeding. Virginia Cooperative Extension, Publication 420-256: 1-4.

Flores-Miranda MC, Gonzalez LA, Cortes-Espinosa VD, Cortes-Jacinto E, Fierro-Coronado AJ, Alaves-Ruiz P, Gonzalez-Ocampo AH, Escamilla-Montes R. 2014. Bacterial fermentation of Lemna sp. as a potential subtitute of fish meal in shrimp diets. African J Microbiol Res 8 (14): 516-526.

Gatesoupe JF, Huelvan C, Bayon LN, Severe A, Aasen MI, Degnes FK, Mazurais D, Panserat S, Zambino-Infate LJ, Kaushik JS. 2014. The effect of dietary carbohydrate source and forms on metabolic response and intestinal microbiota in seabass juveniles, Dicentrarchus labrax. Aquaculture 422-423: 47-53.

Handadjani H, Widodo W. 2010. Fish Nutrition. UMM Press, Malang. [Indonesian]

Handayani S. 2006. The study of the efficient utilization of carbohydrate in diets for the growth of carp (Osphronemus gouramy Lac.) in line with changes in digestive enzymes and insulin. (Dissertation). School of Grauates, Bogor Agricultural University, Bogor. [Indonesian]

Hatlen B, Grisdale-Helland B, Helland JS. 2005. Growth, feed utilization, and body composition in two size groups of Atlantic Halibut (Hippoglossus hippoglossus) fed diets differing in protein and carbohydrate content. Aquaculture 249: 401- 408

Higgs AD, Sutton NJ, Kim H, Oakes DJ, Smith J, Biagi C, Rowshandeli M, Devlin HR. 2009. Influence of dietary concentrations of protein, lipid and carbohydrate on growth, protein and energy utilization, and plasma titers of growth hormone and insulin and insulin-like growth factor-1 nontransgenic and growth hormone transgenic coho salmon, Oncorhynchus kisutch (Walbaum). Aquaculture 286: 127-137.

Huisman. 1976. Food Convertion Efficiencies. At maintenance and production levels for carp, Cyprinus carpio, and rainbow trout, Salmo gairdneri Richardson. Aquaculture 9 (1): 259-273.

Hutchins GC, Rawles DS, Gatlin III DM. 1998. Effects of dietary carbohydrate kind and level on growth, body composition and glycemic response of juvenile sunshine bass, Morone chrysops $\widehat{\jmath} x M$. saxatilis . . Aquaculture 161: 187-199.
Kesavanath P, Manjappa K, Gangadhara B. 2002. Evaluation of carbohydrate-rich diets trough common carp culture in manured tanks, (Abstracts). Aquacult Nutr 8: 169-174.

Krogdahl A, Hemre TG, Mommesen PT. 2005. Carbohydrate in fish nutrition: digestion and absorption in the post-larval stage. Aquacult Nutr 11: 103-122.

Law TA. 1984. Nutritional study of jelawat, Leptobarbus hoevenii (Bleeker) fed on pelleted feed. Aquaculture 41: 227-233.

Mohapatra M, Sahu PN, Chaudhari A. 2003. Utilization gelatinized carbohydrate in diets of Labeo rohita fry. Aquacult Nutr 9: 189-196.

Moreira IS, Peres H, Couto A, Enes P, Oliva-Teles A. 2008. Temperature and dietary carbohydrates level effects on performance and metabolic utilization of diets in European sea bass (Dicentrachus labrax) juveniles. Aquaculture 274: 153-160.

Mulyasari, Kurniawati F, Setiawati M. 2013. Cassava digestibility through chemical and biological treatment as feed for tilapia. Indonesian Aquaculture Journal 12 (2): 178-185. [Indonesian]

Obe, Wurola B. 2014. Growth performance and nutrient utilization of catfish hybrid (Heterobranchus bidorsalis x Clarias gariepinus) fed fermented sorghum (Sorghum bicolor) waste meal diets. International Journal of Applied Science and Technology 4 (3): 130-136.

Perez L, Gonzalez H, Jover M, Fernandez-Carmona J. 1997. The growth of European sea bass fingerlings (Dicentrarchus labrax) fed extruded diets containing varying levels of protein, lipid, and carbohydrate. Aquaculture 156: 183-193.

Prawiroharsono S. 2007. Potential for industrial development and bioeconomics based on traditional fermented foods. Journal of Pharmaceutical Sciences Indonesia (5) 2: 85-91. [Indonesian]

Rostika R. 2010. Improved corncob quality through fermentation of Trichoderma sp, Aspergillus sp, Rhizopus oligosporus and its consortium as carbohydrate source of fish feed and its effect on tawes performance (Puntius gonionitus). (Dissertation). Graduate Program of Padjadjaran University, Sumedang. [Indonesian]

Shan H, Liang FX, Li L, Sun J, Shen D. 2013. Differential gut growth, gene expression, and digestive enzyme activities in young grass carp (Ctenopharyngodon idella) fed with plant and animal diets. Aquaculture 410-411:18-24.

Simon J.C. 2009. The effect of carbohydrate source, inclusion level of gelatinized starch, feed binder and fishmeal particle size on the apparent digestibility of formulated diets for spiny lobster juveniles, Jasus edwardsii. Aquaculture 296: 329-336.

Storebaken T, Sheare DK, Refstie S, Lagoki S. Interaction between salinity, dietary carbohydrate source and carbohydrate concentration on the digestibility of macronutrients and energy in rainbow trout (Oncorhynchus mykiss). Aquaculture 163: 347-359.

Sudarmadji S, Haryono B, Suhardi. 1993. Analytical Procedures for Food and Agricultural Materials. Liberty. Yogyakarta. [Indonesian]

Suhenda N, Samsudin R, Melati I. 2010. Increasing the quality of vegetable materials (rice bran and pollard) through fermentation (Rhizopus oligosporus) and its use in the diets for common carp (Cyprinus carpio). In: Sudrajat A (ed). Proceedings of the Aquaculture Technology Innovation Forum. [Indonesian]

Suprayudi AM, Edriani G, Ekasari J. 2012. Evaluation of fermented product quality of various byproduct of local agroindustry: its influence on digestibility and performance of juvenile growth of common carp. Indonesia Aquaculture Journal 11 (1): 1-10.

Takeuchi T. 1988. Laboratory work-chemical evaluation of dietary nutrients In: Watanabe T. (eds.). Fish Nutrition and Mariculture. Japan, JICA Textbook, The General Aquaculture Course. Departement of Aquatic Biosciences, Tokyo University of Fisheries, Tokyo.

Warta Pasarikan. 2010. Jelawat is belle from number province. Domestic Market Directorate, Directorate General of Processing and Marketing of Fishery. Marine and Fisheries Ministry, Jakarta. [Indonesian].

Yuan X, Zhou Y, Liang FX, Li J, Liu L, Li B, He Y, Guo X, Fang L. 2013. Molecular cloning, expression and activity of pyruvate kinase in grass carp Ctenopharyngodon idella: Effects of dietary carbohydrate level. Aquaculture 410-411 (2013) 32-40.

Zambonino JL, Cahu C. 1999. High dietary lipid levels enhance digestive tract maturation and improve Dicentrarchus labrax larval development. J Nutr 129: 1195-1200.

Zhang LL, Zhou CQ, Cheng QY. 2009. Effect of dietary carbohydrate level on growth performance of juvenile spotted babylon (Babylonia areolata Link 1807). Aquaculture 295: 238-242. 